\title{
ARCHEOLOGICZNE ŚCIEŻKI SEWERYNA TYMIENIECKIEGO - KWIATKÓW W BADANIACH ARCHIWALNYCH KALISKIEGO PRAWNIKA
}

\author{
THE ARCHAEOLOGICAL PASSIONS OF SEWERYN TYMIENIECKI - \\ KWIATKÓW IN THE KALISZ-BASED LAWYER'S ARCHIVAL RESEARCH
}

\begin{abstract}
This article is meant to present and verify historical objects discovered in Kwiatków (Gaj) village by Seweryn Tymieniecki (1847-1916). These relics (related to the Lusatian and Przeworsk cultures) are a good pretext for presenting the lawyer from Kalisz who was also an avid fan of archaeology. On top of a collection of interesting artefacts, Tymieniecki described equally intriguing burial forms. He made a name for himself in literature on the subject owing to his activity in the field followed by numerous publications in which he presented the effects of his surveys in a professional and competent way. It took 130 years before Tymieniecki's name appeared again in archaeological literature. However, this time it was an entirely different quality of research, with respect to the methodology as well as the results of the work.
\end{abstract}

Keywords: archival research, archaeology, Kwiatków, Seweryn Tymieniecki, $19^{\text {th }}$ century

Kwiatków (gm. Brudzew) to niewielka wieś położona w dolinie Warty na granicy województwa łódzkiego i wielkopolskiego. Dzięki prowadzonym tam kilka lat temu badaniom wykopaliskowym, w związku z poszerzeniem kopalni odkrywkowej węgla brunatnego „Koźmin”, Kwiatków stał się jednym z ciekawszych odkryć archeologicznych ostatnich lat (Kot, Piotrowska i Schellner 2015; Rzepecki, Kot i Piotrowska 2016). To szczególne stanowisko kojarzy się głównie z rozległą osadą kultury przeworskiej', na której zrejestrowano niespotykany dotąd zespół

* ORCID: 0000-0003-3774-2784; Instytut Archeologii, Uniwersytet Łódzki, ul. Narutowicza 65, 90-131 Łódź, karolina.kot@uni.lodz.pl.

${ }^{1}$ Rozpoznano wiele materiałów zarówno ceramicznych, jak i pozaceramicznych, które nawiązują do ceramiki kultury jastorfskiej. Jest to o tyle ważne, iż dotychczas poniżej równoleżnikowego biegu środkowej Warty nie rejestrowano stanowisk z materiałami schyłkowojastorfskimi i wczesnoprzeworskimi. Dalszy rozwój osadnictwa wiąże się tu z okresem rzymskim i wczesnymi fazami wędrówek ludów. Apogeum rozwoju osadnictwa na stanowisku (strefa A1, A2) przypada na okres rzymski. Z tego 
studni liczący ponad 100 takich obiektów (Piotrowska 2016). Na uwagę zasługuje także wczesnośredniowieczne cmentarzysko. Stanowisko to dostarczyło wielu unikatowych znalezisk i stało się także źródłem wiedzy na temat dawnych społeczeństw zamieszkujących okolice gminy Brudzew (Piotrowska 2016, s. 47-140).

Jednak Kwiatków to nie tylko wspomniane szerokopłaszczyznowe badania ratownicze, ale również źródła archiwalne. Informacje na temat zabytków archeologicznych z najbliższej okolicy zaistniały w literaturze już dużo wcześniej. Pierwsza wzmianka dotycząca rejonu Brudzewa pojawiła się w 2. połowie XIX w. za sprawą Józefa Ignacego Kraszewskiego. Pisze on, co następuje „Przeszła także do zbioru (Towarzystwa Przyjaciół Nauk) ...popielnica wielka, gliniana, z dwóma mniejszymi, wykopana pod Brudzewem o milę od Koła w Kaliskiem w r. 1827" (Kraszewski 1860, s. 152). Wspomniane dzieło pozbawione jest warstwy ilustracyjnej opisywanych w nim zabytków. Dodając do tego ich niezbyt szczegółowy opis, nie ma możliwości chronologicznej i kulturowej weryfikacji opisanych przedmiotów.

Należy przypomnieć, że połowa XIX w. to czas dynamicznego rozwoju archeologii, kiedy licznie powstawały towarzystwa zajmujące się starożytnościami, organizujące wystawy oraz wydające publikacje dotyczące znalezisk i odkryć archeologicznych.

Bardzo ważną postacią dla okolic Kalisza okazał się Seweryn Tymieniecki (1847-1916, ryc. 1). Z zawodu prawnik, z zamiłowania działacz społeczny, numizmatyk, bibliofil, kolekcjoner pamiątek historycznych i zabytków archeologicznych $^{2}$. Amatorskie badania, w ostatniej $\mathrm{z}$ wymienionych dziedzin, rozpoczął w latach siedemdziesiątych XIX w., a obejmowały one obszar ówczesnej Guberni Kaliskiej. Wspomniany badacz wyniki badań publikował m.in. w „Zbiorze Wiadomości do Antropologii Krajowej”, „Pamiętniku Fizyograficznym”, „Materyałach Antropologiczno-Archeologicznych i Etnograficznych Akademii Umiejętności” czy „Roczniku Prawników Kaliskich” (Abramowicz 1991, s. 30). To właśnie dzięki niemu Kwiatków szerzej zagościł w literaturze.

Niniejszy artykuł ma za zadanie przedstawienie zabytków zarówno z okresów wcześniejszych, jak i z okresu funkcjonowania kultury przeworskiej, które pojawiły się w pracach Seweryna Tymienieckiego. Na obecnym etapie opracowywania materiałów z tego stanowiska nie stwierdzono obecności źródeł związanych z kulturą łużycką bądź kulturą pomorską (Kot i Piotrowska 2016, s. 287-302). Ze znaleziskami „łużyckimi” mamy natomiast do czynienia w artykułach dotyczących

przedziału czasowego, poza ceramiką, zarejestrowano bogaty zbiór zabytków metalowych (co na stanowiskach osadniczych należy do rzadkości), w tym wiele zabytków unikatowych, jak np. szklane pionki do gry; pojawiły się także artefakty, które dotychczas znane były głównie z cmentarzysk (por. Kot 2016, s. 141-274; Kot i Piotrowska 2016, s. 275-286; Rzepecki, Kot i Piotrowska 2016).

2 Naukowe zainteresowania Seweryna Tymienieckiego szczegółowo analizuje Tadeusz Baranowski, prezentując nie tylko archeologiczną działalność kaliskiego prawnika, ale i jego drugą, niemniej ważną pasję, jaką była numizmatyka (Baranowski 1995, 14-23). 


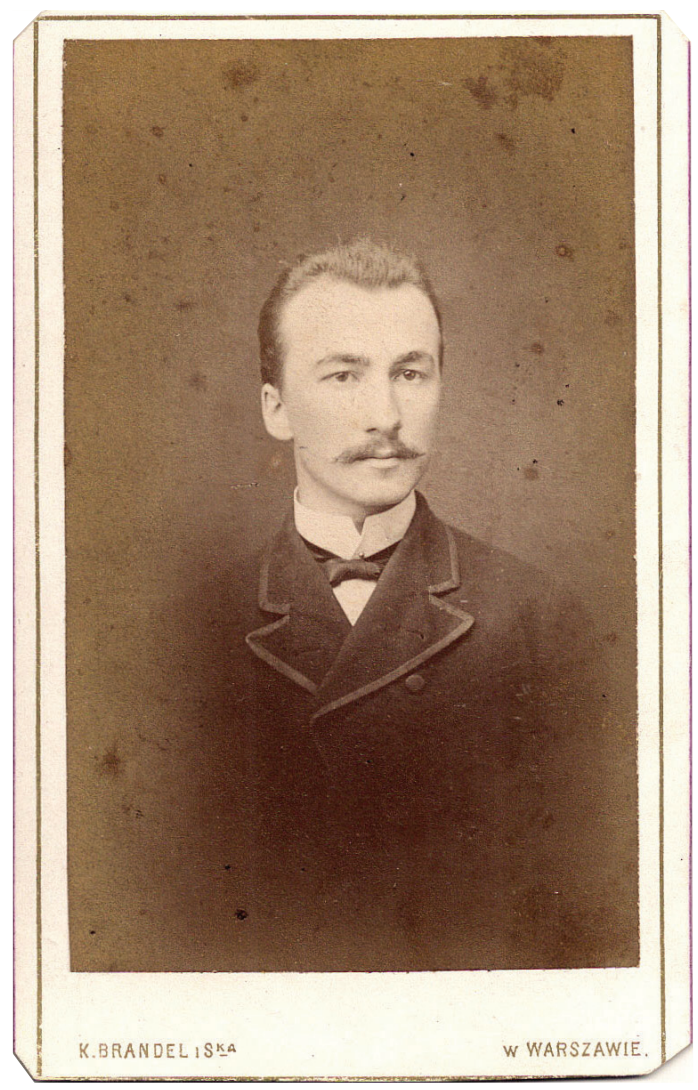

Ryc. 1. Seweryn Tymieniecki (1847-1916) (źródło: http://www.info.kalisz.pl/biograf/tymienie mob.htm)

amatorskich wykopalisk archeologicznych prowadzonych w okolicach Kwiatkowa przez wymienionego wyżej kaliskiego miłośnika starożytności. Omówienie znalezisk warto zacząć od krótkiego zarysowania historii badań na terenie Kwiatkowa i dotyczących ich publikacji.

Pierwsza wzmianka pochodziła z 1878 r., a zamieszczona została w „Zbiorze Wiadomości do Antropologii Krajowej”, gdzie Tymieniecki wymienia Kwiatków jako jedno z cmentarzysk ,przedhistorycznych” z okolic Kalisza (Tymieniecki 1878, s. 76, tabl. IV.B: fig. 4). W artykule tym, dotyczącym „przedhistorycznych” cmentarzysk znad Neru i Warty, znalazła się informacja na temat odkryć pochodzących z cmentarzyska zlokalizowanego w niedalekiej odległości od badanej w ostatnich latach osady, po drugiej stronie Warty i Teleszyny. Kilka lat później w „Pamiętniku Fizyograficznym” S. Tymieniecki w całości poświęcił starożytnej 
nekropolii swój artykuł pt. Żalnik w Kwiatkowie (Tymieniecki 1881). Kolejne publikacje dotyczące Kwiatkowa to dwa artykuły autorstwa kaliskiego badacza wydrukowane w „Gazecie Kaliskiej” (ryc. 2), które ukazały się w sierpniu 1904 r. (Tymieniecki 1904). Dowiadujemy się z nich o poszukiwaniach stanowiska w Kwiatkowie oraz samych wykopaliskach. W roku 1906 ukazały się kolejne artykuły w „Materyałach Antropologiczno-Archeologicznych i Etnograficznych” oraz w „Roczniku Prawników Kaliskich” (Tymieniecki 1906a; 1906b). Dwie z wymienionych prac zasługują na szerszy komentarz.

We wspomnianym wyżej „Pamiętniku...” ukazał się dłuższy artykuł, w całości poświęcony odkryciom z Kwiatkowa. Z niezwykle barwnego opisu okolicy wynika, iż cmentarzysko zlokalizowane było na niewielkim, piaszczystym wyniesieniu i już wtedy było to stanowisko zniszczone (Tymieniecki 1881, s. 1-6). Prawdopodobnie sam Tymieniecki prowadził tam badania w 1880 roku. Nie podaje dokładnej liczby odkrytych grobów ani odkrytych w nich darów grobowych. Pozostałości cmentarzyska znajdowały się płytko, a na powierzchni widoczne były zarówno fragmenty naczyń, jak i przedmioty metalowe (Tymieniecki 1881, s. 1-2). Wśród wymienionych w artykule zabytków znalazły się umba, groty, imacze, noże, nożyce, zapinki, klucze, paciorki szklane oraz fragmenty ceramiki (ryc. 3; Tymieniecki 1881, tabl. XIII).

Analiza zabytków umieszczonych we wspomnianym artykule nie pozostawia wątpliwości, iż mamy do czynienia z wyposażeniem grobowym kultury przeworskiej z okresu rzymskiego. Na taką proweniencję wskazują nie tylko zabytki metalowe, ale także ceramika i jej fragmenty, w tym ułamek terra sigillata (ryc. 3:6). Wspomniany ułamek naczynia należy do grupy IIb z warsztatu Juliusa I z ośrodka Rheinzabern i łączony jest z czasami panowania Sewerów (Tyszler 2012, s. 56, 195). Fragment terra sigillata został znaleziony przez badacza pomiędzy innymi fragmentami ceramiki zalegającymi na powierzchni. Podaje, iż wykonano go z gliny popielatej bez śladów domieszki (taki kolor naczynia sugeruje, że zostało wtórnie przepalone). Ornament to „wypukłe” przedstawienie siedzącego zająca umieszczone w „obwódce eliptycznej” (Tymieniecki 1881, s. 2, tabl. XIII:6). Badacz słusznie zauważa również, że do powstania takiego rodzaju wypukłego ornamentu (i naczynia) musiała zostać użyta forma (Tymieniecki 1881, s. 2, tabl. XIII; Tyszler 2012, s. 53). Z taką chronologią kłóci się natomiast forma grobów, w których te zabytki miały się znajdować. „Groby cmentarzyska tego w swej budowie bardzo zwykłe; formy prostokątnych skrzynek, wykładanych z boków, spodu i przykrytych z wierzchu kamieniami łupanemi w nieregularne bryły. Urny same, których w każdym grobie po kilka, lepione ręką, inne toczone na kole garncarskiem..." (Tymieniecki 1881, s. 1). Autor opisuje i zamieszcza rysunki trzech z nich (ryc. 3:1-3), które jako jedyne zachowały się w całości (Tymieniecki 1881, s. 2, tabl. XIII:1-3). Na podstawie zamieszczonego rysunku można przypuszczać, że jedno z naczyń może być formą „łużycką” (ryc. 3:1), a analogiczne są spotykane od IV okresu epoki brązu po wczesny okres epoki żelaza (Kaszewski 1969, 


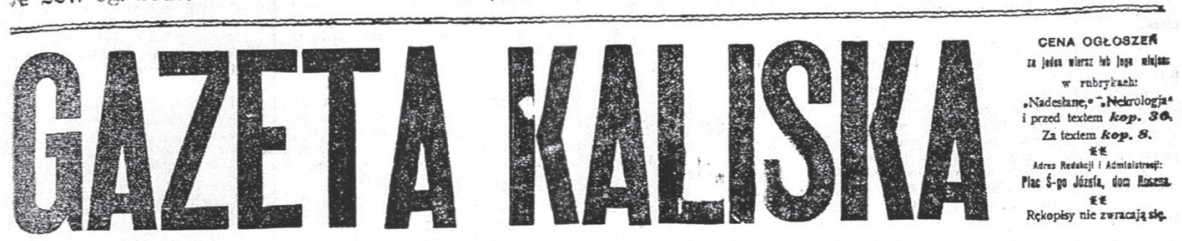

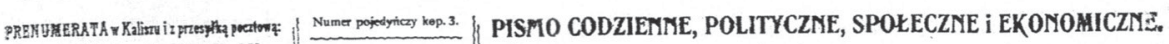

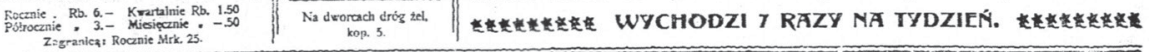

Zakład Naukowy Żeński Heleny Semadeniowej,

ulica Nowo-0grodowa, dom W-go inz. Szrajera.

$\mathrm{Z}$ jis vezecnic rozpoczety. Poezatek psuls duia 5

Lecznica chorób zębów 1 Jarny ustne]

Maksymiljana Zucker,

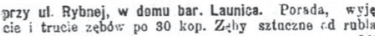

- Dzisiejszy nuner „Gazety Kallskiej" wyszeet

Zabytki przedhistoryczne $\mathrm{z}$ nad Neru i Warty, a zwłaszcza cmentarzysko w Kwiatkowie.$$
\text { Spisal }
$$$$
\text { seweryn Tymienieckl. }
$$

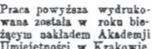

W Pewiętriku Kizjograficzoym, wJdaoyo w $1881 \mathrm{r}$. w. Wirsca rie, pomieszezoeem byto lróftbie sprawozda. lutseh dalsze poszukiwania w temże miejscto, a próez togo badsiac ukolice saraa, zdobylew dosé obfity pion, sił prague.
Oselies, w której poszuliwasuis moje robiter, ogolngm zarysie przedstawia sie w furmie tróikats, wy wrócon go pidta wa hu polack. Bok jego stavowia gach bìstami i leremi, ze wrchodu Ner, który w granicach $*$ si Bielasy i Kosew 2 wraesjąc się nagle $x$ kie ranka swego od putodsia ku poitury na lewo i plyna

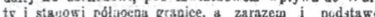
trílikato.

Worta na calej przestrzoni, zaczawszy od Uuiejowa
kola, nia napotyka po drodze swej na zadae wyż sze terytorjum pierwutaej furmacii, ktoreby bieg jej zwra.

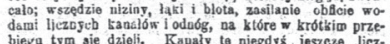
biega tym sie dzieli. Kauajy to niegdy' jesseze liez-
niejszymi były, dzis w częsti wyschle, zamienione na pola orue, lub śrb́d hak w wazki rów ujete, w tradscj tyllio, nazwie rzeks" lab stare koryto s slady piferso. taego by tu zachowaly. Na gruotach wsi Skotviki, dzis
sród fojl oraych po lewej strovie drogi wiod powa Dolnegu, w odleglości moiei wiecej póttorej wior mi zagkebienie, ciagnace sie pasem od poludpin dy pot

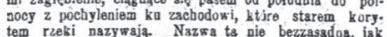

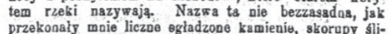

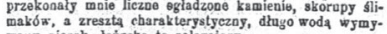
mavy piasel, tožzskso to zalegajacy.

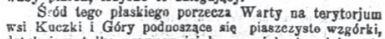
dotylyaizce tgliko prawego jej brzegu, jak niembiej $\mathbf{w y z}$ -

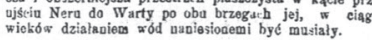

Ner w biegu six ym 2 potudnia ku póluocy do miej-

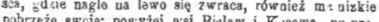
rej itronie wpadajuej to się pcdnosi, two:ząc brawedź ze erschedu kn zachedowi

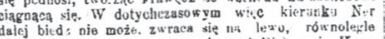

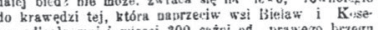

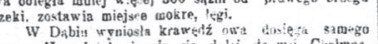

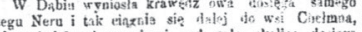

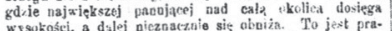
wie porzecze Natu. Porzecze lowo odraiengr, o wielo nizsze, brzeg sam pokryty legami, w wiela miejzeses tak btotny, ze naret us rsod skwaruegs lata aie wysycha.

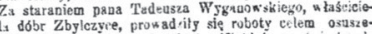
ia błot i zamienienis ich or legi. Nizki brzez tea ciagnie

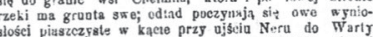
os terytorjum Kwiatkoura, przochodzace dalej ps lewe stronie Wrotty przez Giowy. Lẹki do Kuscelca, slad
ka zaebodowi otwiers się sarha phaska okolica. Pos lak i blot, ejagrages się wzdłoz lewego brzegn

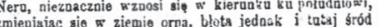

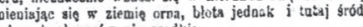

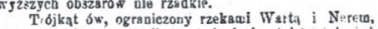

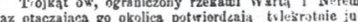
obserw owany zwyezai Ind oi przedbistoryczaych czasśw,

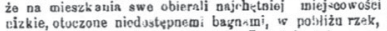

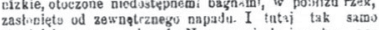
gie dziato: prawe pobrexta Nern wynioste i suthe po ryte było lasami, niezamieszkaie.
Przezoays aja munie o tem dwie głorne okoliczas.

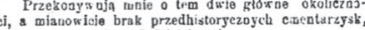
sci, a mianowiale brak przedhistorye
oraz nazws wsi i osad dzisiejszych.

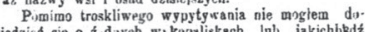

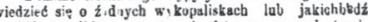
Sladzech p zedhistoryczoego czlowioka po prawej stroni: Neru. Nazw ska mieiscon osei niewatpliwie niezmievian

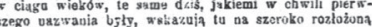
paszezą lésna. ce, Debowicie, Olszówka, Diececilorvo, Snardzeaso. O:

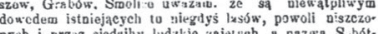
ngeb i przaz siedziby ludzkie zajetreb, a pazwa S. bót-

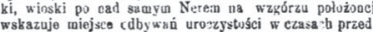
wskazuje rniejsco cdbywan urozzystuści w czasa-b przed.
dziejounych. Lewe porzerze a podstawy wzmianko wanego trói. jalk na owe czasy osiedlonem brly. Dowodem tego s? tu cmentarzo, to $i$ owdzie zoajdowane narzedcia pier
wotae, nasypy $i$ iove zreszta slady przedhistoryczneg

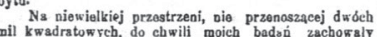
mil kwadratowych, do ebwili, moich badsi zachowaly

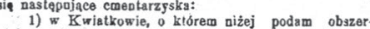
giejsza riadomusks;

adowan Cropowie Dolaym, na pola frzylegajacerm di czerepów od ura, tu i oxdzie szezatki przepalonyet

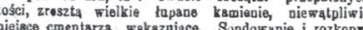
vacie do żadoych nio doprowsadzito razultatóz: ask bliskie zsbudowan od dawnych lat pod uprawe tywane bylo, wigc powoli plug rozruszal groby; przed
kilkunastu laty jeduak wydobsto tutaj cale jeszece s) w sasiedniej wiosee Skutaikacb, nie wircej iak Cwiere wili od Czepuwa cdlestej, znalazlean takież same

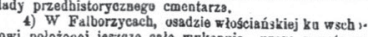
dowi polożoej jestcze calo wykopuja uroy; camentarza ieczýnski, whasceciel sysiedniei ysi R żoiatowa.

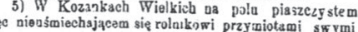

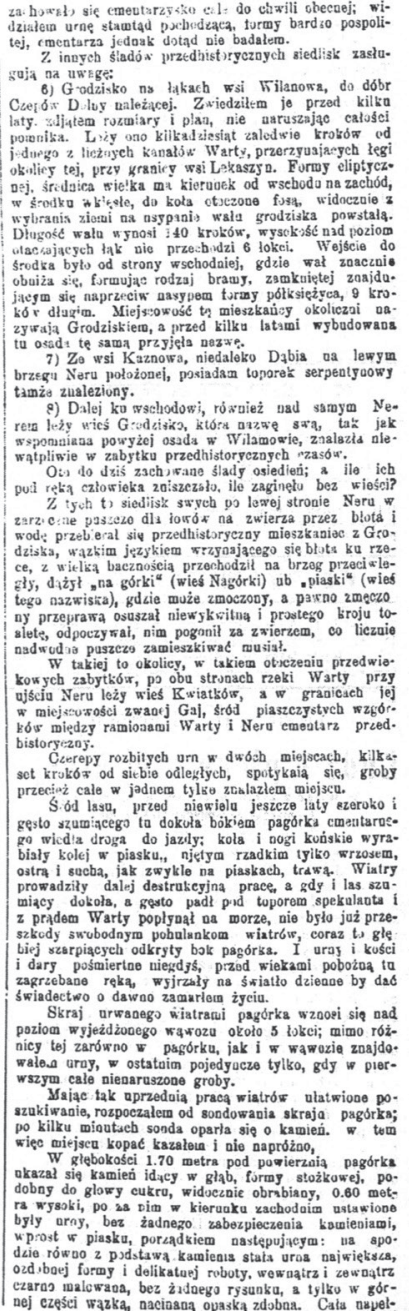

Ryc. 2. Strona tytułowa „Gazety Kaliskiej”, nr 227, z dnia 5 sierpnia 1904 roku (Tymieniecki 1904) 
s. 78). Pozostałe to formy kultury przeworskiej. Nie rozstrzygniemy niestety czy, i które naczynia, rzeczywiście znajdowały się wewnątrz wspomnianych konstrukcji. Najprawdopodobniej w tym samym miejscu istniały dwa cmentarzyska. Starsze, z konstrukcjami kamiennymi w formie skrzyń, należy łączyć z kulturą łużycką. $\mathrm{W}$ istniejące już założenia grobowe wkopano (zapewne przypadkowo) groby z okresu rzymskiego reprezentujące kulturę przeworską. Świadczy o tym fakt, że w odkrytych przez Tymienieckiego urnach znajdowały się nie tylko przepalone kości wraz z resztkami stosu i piaskiem, ale i zabytki o przeworskiej proweniencji (ozdoby, broń, przedmioty codziennego użytku), które opisuje w dalszej części artykułu. Nie przyporządkowano ich jednak do poszczególnych zespołów grobowych, omówione zostały jako jeden homogeniczny zbiór.

Pierwsze opisane zostały dwa umba z tępym, krótkim, kolcem z tępymi kolcami (ryc. 3:7, 8) prezentujące typ J.7a odmiany $1 \mathrm{wg}$ T. Liany, natomiast w typologii N. Zielinga umba zbliżone są do typu B1 (Tymieniecki 1881, tabl. XIII:7-8; Zieling 1989, s. 1015; Liana 1970, s. 451-452)3. Tymieniecki zamieszcza również rysunek imacza (ryc. 3:9) typu J.9, który występuje w 5 i 6 grupie grobów z bronią faz C1a i C1b (Tymieniecki 1881, tabl. XIII:9; Godłowski 1992, s. 72-74). Następnie autor wymienia cztery groty ${ }^{4}$, wspomina również o pięciu nożach (ryc. 3:10-15; Tymieniecki 1881, s. 4, tabl. XIII:10-15.), z których przedstawiono dwa5 Pierwszy to egzemplarz o masywnym ostrzu długości $16 \mathrm{~cm}, \mathrm{z}$ prostą głownią i trzpieniem obustronnie wyodrębnionym pod kątem prostym (ryc. 3:14; Tymieniecki 1881, tabl. XIII:14). Drugi nóż o długości ostrza $6,5 \mathrm{~cm} \mathrm{z}$ tylcem lekko łukowatym i trzpieniem wyodrębnionym pod kątem rozwartym (ryc. 3:15; Tymieniecki 1881, tabl. XIII:15). Analogiczne okazy wystąpiły na cmentarzysku w Siemiechowie, stan. 2, woj. łódzkie, gdzie łączone były $\mathrm{z}$ fazami B1-B2 okresu rzymskiego (Jażdżewska, Siciński 2017, s. 51), aczkolwiek, ogólnie nie są to zabytki „czułe” chronologicznie.

Kolejnym zabytkiem wymienianym przez Tymienieckiego są nożyce (ryc. 3:16), nie podaje jednak ich wielkości (Tymieniecki 1881, s. 4, tabl. XIII:16). Wspomina również o „pięciu haczykach”, które według niego „służyły do zamykania drzwi do domów lub sprzętów domowych" (Tymieniecki 1881, s. 4, tabl. XIII:17-20). W rzeczywistości są to klucze i elementy konstrukcyjne skrzynek. Pierwszy z nich to klucz z jednym piórem w kształcie litery „U” (ryc. 3:17; Tymieniecki 1881, tabl. XIII:17), można go powiązać z typem A wg Kokowskiego (Kokowski 1997, s. 36). Wydaje się, że kolejny z kluczy posiada płaski, szeroki trzon, w związku z tym odpowiadałby typowi A2 wg Kokowskiego (ryc. 3:18; Tymieniecki 1881,

${ }^{3}$ Datowanie umb zaliczonych do grupy B1 zawiera się w szerokich ramach chronologicznych, od okresu przedrzymskiego do fazy C1a (Zieling 1989, s. 1049).

${ }^{4}$ Brak określenia zależności metrycznych w znacznym stopniu uniemożliwia określenie typologiczne.

${ }^{5}$ Autor nie podaje całkowitej długości zabytków, jedynie długość ostrzy. 


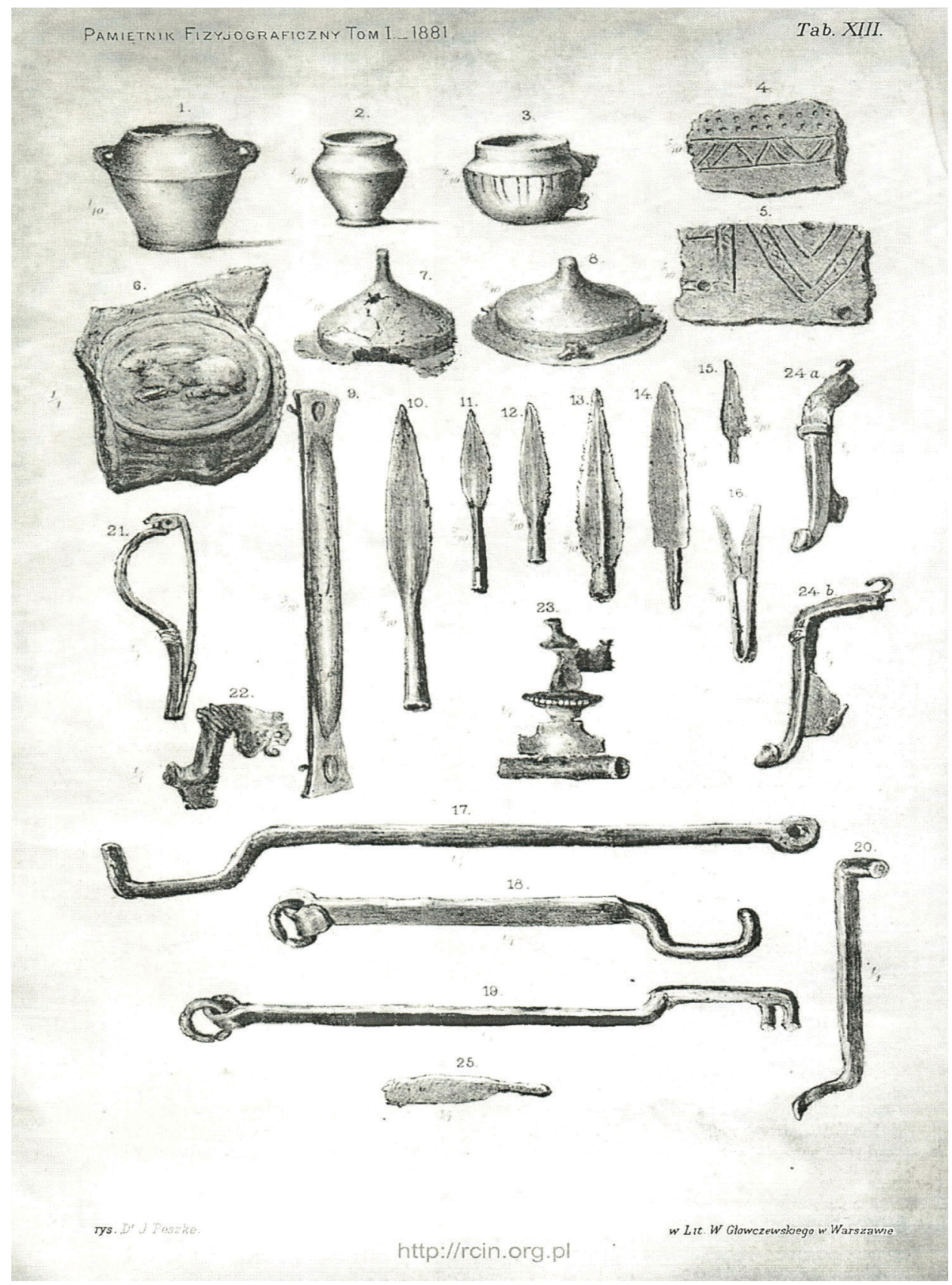

Ryc. 3. Wybór zabytków z żalnika w Kwiatkowie (Tymieniecki 1881, tabl. XIII) 
tabl. XIII:18; Kokowski 1997, s. 36). Trzeci z tej grupy zabytków miał dwa pióra, co pozwala zaliczyć go do typu C (ryc. 3:19; Tymieniecki 1881, tabl. XIII:19; Kokowski 1997, s. 36). Ostatnie dwa ,haczyki” wyróżnione przez badacza to najprawdopodobniej element mechanizmu zamka skrzynki (sprężyna) (ryc. 3:20; Tymieniecki 1881, tabl. XIII:20; Kokowski 1997, Abb.1).

Klucze typu A najczęściej występują na cmentarzyskach przeworskich w fazach B2-B2/C1, natomiast typ A2 rejestrowany jest od końca fazy B2 po C1 włącznie; niewykluczone, że pojawiały się nadal w fazie C2 (Kokowski 1997, s. 40). Klucze z dwoma piórami rejestrowane są dla zespołów grobowych z faz B2 i B2/C1-C1 (Kokowski 1997, s. 41).

Wśród opisywanych zabytków znalazły się również fibule. Można tu rozpoznać okaz silnie profilowany IV grupy wg O. Almgrena (ryc. 3:22), który w typologii T. Liany odnajduje odpowiednik w odmianie 1 wiązanej $\mathrm{z}$ fazą B1, a dokładnie wyznacznik podfazy B1c (Tymieniecki 1881, tabl. XIII: 22; Liana 1970, s. 442-443; Godłowski 1985, s. 41). Następny egzemplarz to brązowa zapinka z podwiniętą nóżką grupy VI, serii 1 (A158) o trudnym do zidentyfikowania podtypie (ryc. 3: 21; Tymieniecki 1881, tabl. XIII: 21; Almgren 1923). Dalej Tymieniecki wskazuje na odnalezienie dwóch jednakowych fibul, ale o różnym stopniu zachowania. Podaje również, że wykonano je z różnych metali, kapturki najprawdopodobniej były żelazne, pozostała część zapinek wykonana została z brązu (Tymieniecki 1881, s. 5-6, tabl. XIII:23). Tymieniecki publikuje rysunek jednej z nich (ryc. 3: 23). Zamieszczona rycina przedstawia zabytek zniszczony, ale mimo stanu zachowania jest to klasyczny przykład fibuli A43 datowany na fazę B2/C1 (Almgren 1923; Godłowski 1970, tabl. I: 52; Domański 1979, s. 20; Olędzki 1998, Abb. 18, s. 82).

Wydaje się, iż kolejny okaz, niestety również zachowany fragmentarycznie (ryc. 3: 24a,b), może nawiązywać do fibul określonych jako pochodne od silnie profilowanych i wiązać się z końcem fazy B2 po C1 włącznie (Tymieniecki 1881, tabl. XIII:24a, b; Liana 1970, s. 444, tabl. III:22). Można doszukiwać się tu również analogii wśród mazowieckich odmian późnych fibul 2 serii IV grupy (typ 1B), potwierdzonych dla faz B2/C1 i C1 (Dąbrowska 1995, s. 8, 20).

Kolejne wymieniane przez badacza zabytki to destrukt niewielkiego noża (ryc. 3:25) oraz paciorki (Tymieniecki 1881, s. 6, tabl. XIII:25). W przypadku ostatniej grupy zabytków do paciorków można zaliczyć jedynie pierwsze z wymienionych przez kaliszanina, które wykonane zostały z zielonego szkła ${ }^{6}$, pozostałe zaś były z gliny (ciemnoczerwona i żółta) i zapewne chodzi tu o przęśliki.

Tymieniecki w swoich pracach skupia się nie tylko na opisie zabytków, podejmuje także wysiłek objaśnienia funkcji odkrywanych przedmiotów, a jako analogie przytacza znaleziska z Danii, które oglądał podczas swej podróży do Kopenhagi.

\footnotetext{
${ }^{6}$ Ponieważ S. Tymieniecki nie zamieszcza ilustracji, wszelkie ustalenia dotyczące chronologii oraz typologii są bezpodstawne.
} 
Tymieniecki. Zabytki $z$ nal Nera: Warty.

f.
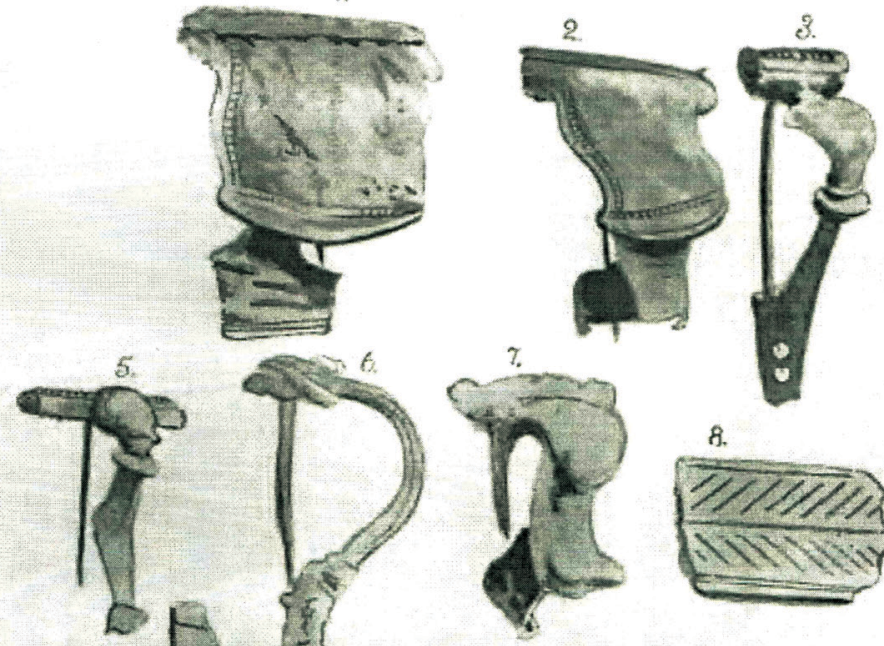

ค.
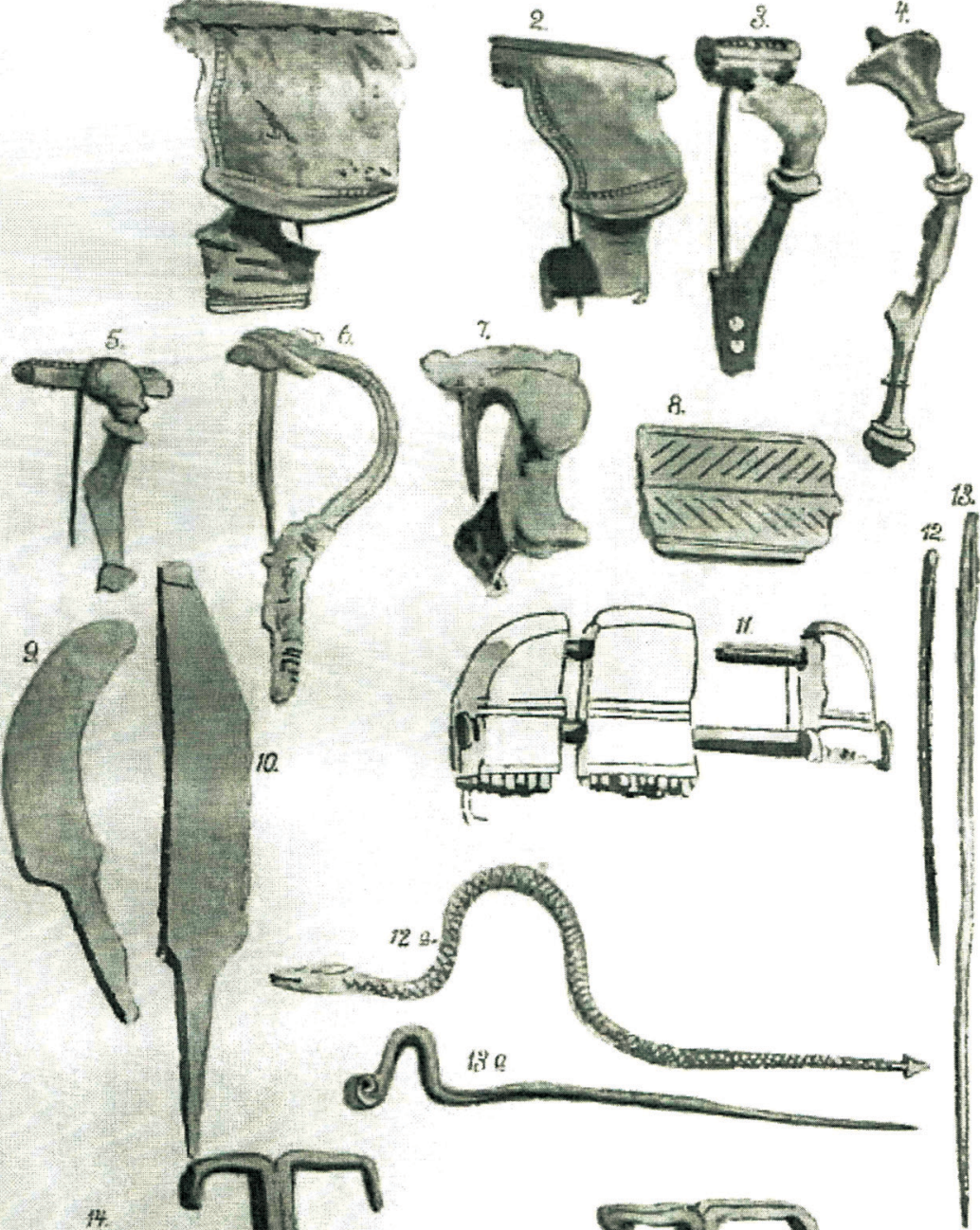

14.
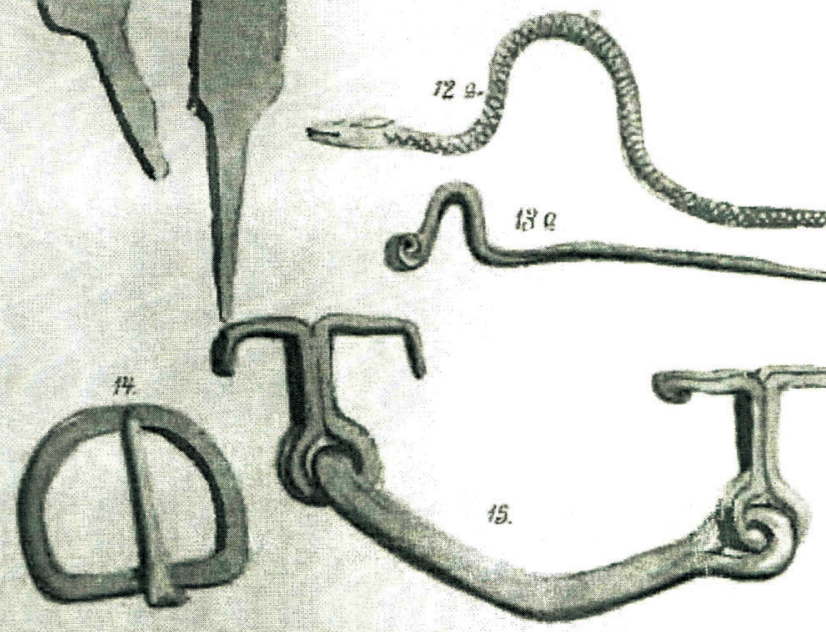

L- inasos

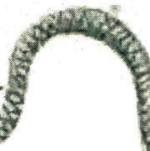

18?
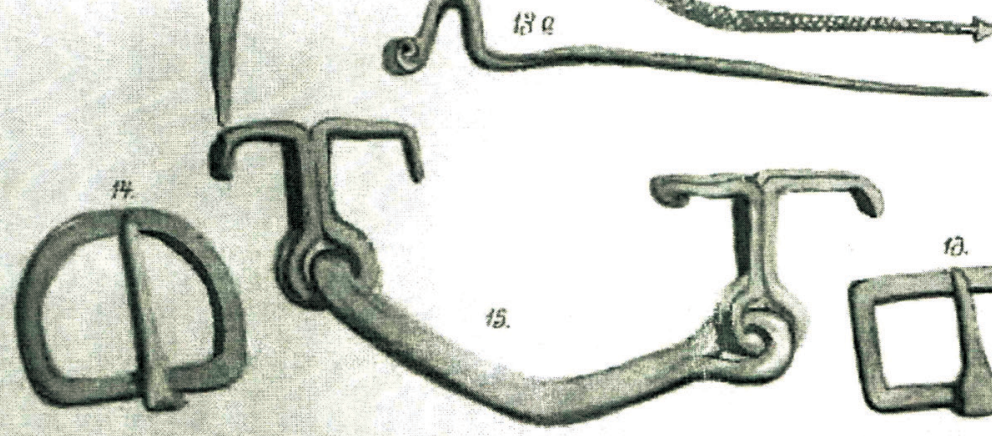

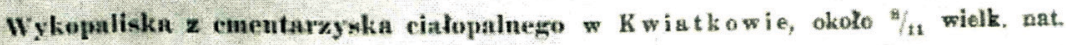

Nr. 1 -5. Zapinki (fibuley bronzowe, - 6. Zapinka kelazna, - 7. Zapinka bronzowa, 8. Iliamek ezdobny z blachy bronzowej, - 9. i 10. Nokyki zolazne, - 11. Grzebień boḱcinoy, ajajany drutem iolaznym, - 12. i 13. Iply zelazne, - 12. a Supila bronzowa, - 13. a Sapila belazna, - 16. i 16 . Sprascaki Lelazne, -. 15. I'rzedmiot ielaeny.

Ryc. 4. Zabytki z cmentarzyska w Kwiatkowie (Tymieniecki 1906a, tabl. I) 
Autor zastanawia się także nad zwyczajami pogrzebowymi ludności użytkującej cmentarzysko w Kwiatkowie (Tymieniecki 1881, s. 3-4).

Najobszerniejsze sprawozdanie ze swoich badań w Kwiatkowie opublikował w 1906 r. w „Materyałach Antropologiczno-Archeologicznych i Etnograficznych” będących efektem kolejnych działań terenowych, nie tylko w Kwiatkowie, ale i w najbliższej okolicy (Tymieniecki 1906a, s. 77, 81). W pracy tej znacznie rozbudowuje wzmianki umieszczone w „Gazecie Kaliskiej”, uzupełniając je o materiał ilustracyjny (ryc. 4-8), powtarza również niektóre informacje zawarte wcześniej w zaprezentowanej wyżej publikacji z 1881 roku. Swój artykuł rozpoczął od „romantycznego" opisu okolic cmentarzyska znajdującego się na piaszczystym wyniesieniu nad Wartą. Podaje, iż przez fragment cmentarzyska wiodła droga, co wraz z częściowym odlesieniem obszaru nie wpłynęło korzystnie na stan zachowania stanowiska. W dalszej części artykułu podał dość szczegółowy opis grobów popielnicowych, którym towarzyszyły obrabiane kamienie (Tymieniecki 1906a, s. 81, 82).

Pierwszy z grobów odkryty został na głębokości $1,7 \mathrm{~m}$, gdzie ukazał się stożkowaty kamień $(70 \mathrm{~cm})$, na zachód od niego, u podstawy ustawione były naczynia: czarna urna „w górnej części wązką, nacinaną opaską zdobna”, wewnątrz znajdowały się przepalone kości oraz dary grobowe (Tymieniecki 1906a, s. 81-82) ${ }^{7}$. Wśród nich wymienione zostały dwie przystawki, które miały znajdować się wewnątrz dużej popielnicy, naczynia to formy cienkościenne o czarnych powierzchniach (ryc. 7:4; 8:1; Tymieniecki 1906a, s. 86, tabl. IV:4; V:1). Z opisu jednego z naczyń wynika, iż oba posiadały ornament charakterystyczny dla naczyń kultury przeworskiej z faz A1-A2 młodszego okresu przedrzymskiego (Tymieniecki 1906a, s. 86, tabl. IV:4, V:1; Kot 2016, s. 165). Na wyposażenie grobu składały się także brązowa fibula (brak rysunku) i żelazne szydło (jw.). Z materiałów zilustrowanych należy wymienić żelazną sprzączkę (ryc. 4:14) o ramie D-kształtnej, którą zaliczyć można do grupy D1 wg R. Madydy-Legutko datowanej zarówno na rozwinięty odcinek fazy B2, jak i późny okres rzymski (Tymieniecki 1906a, tabl. I:14; Madyda-Legutko 1986, s. 24-26) oraz osełkę/krzesak wykonaną z piaskowca (ryc. 6: 24; Tymieniecki 1906a, tabl. III:24). Nad omówioną popielnicą znajdowało się drugie, nieco mniejsze naczynie o analogicznym kształcie zawierające przepalone kości, resztki stosu i piasek (Tymieniecki 1906a, s. 82).

Kontynuując opis znalezisk, wspomina, że w pewnym oddaleniu od omówionych urn (na poziomie wylewu urny znajdującej się najniżej) umieszczona była misa, a wewnątrz niej kubek, naczynia te nie zawierały szczątków. Zwróciły jego uwagę ze względu na sposób wykonania „oba z gliny grubej, roboty ordynaryjnej ręcznej, bez żadnych ozdób lub pomalowania". Natomiast poniżej naczyń zalegała duża liczba zabytków, głównie broń, przedmioty codziennego użytku (Tymieniecki 1906a, s. 82) ${ }^{8}$. Pośród nich miał znajdować się jednosieczny miecz (ryc. 5:19),

\footnotetext{
7 Nie wszystkie opisywane zabytki zostały umieszczone na tablicach.

${ }^{8}$ Brak opisu zabytków i ilustracji.
} 


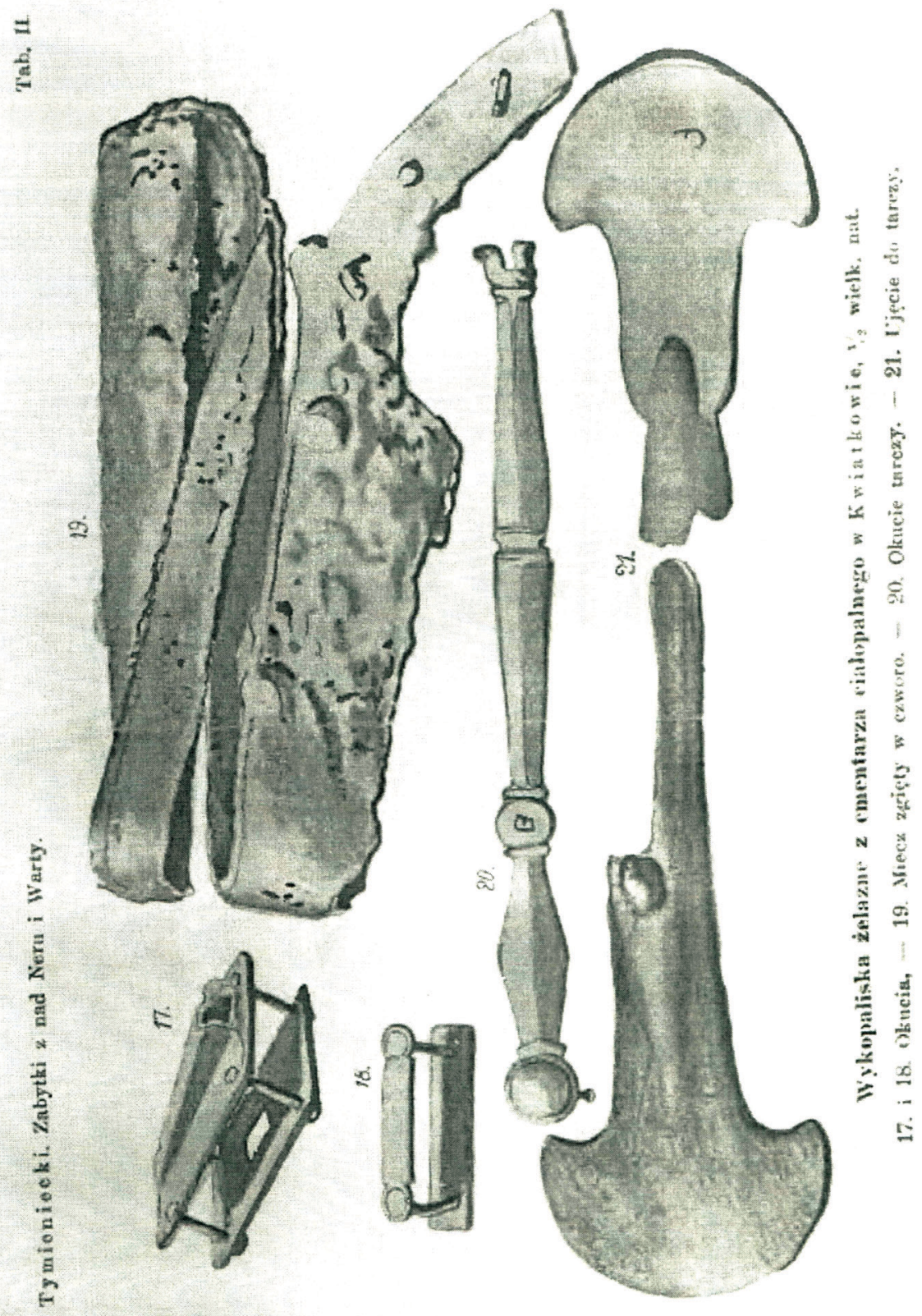

Ryc. 5. Zabytki z cmentarzyska w Kwiatkowie (Tymieniecki 1906a, tabl. II) 
„zgiętym na czworo" o długości $71 \mathrm{~cm}$, szerokości (u nasady) $4 \mathrm{~cm}$, który można powiązać z odmianą B/1 w typologii Biborskiego, charakterystyczną dla fazy B1 i początku fazy B2 (Tymieniecki 1906a, s. 85, tabl. II:19; Biborski 1978, s. 119, 121-122). Granice grobu (wg Tymienieckiego) wyznacza drugi, pionowo ustawiony kamień (Tymieniecki 1906a, s. 82, fig. 2). I w tym przypadku S. Tymieniecki trafił na groby kultury przeworskiej wkopane w założenie kultury łużyckiej. I ponownie, jak przy opisie w „Pamiętniku Fizyograficznym”, kamienne konstrukcje należałoby wiązać ze starszą jednostką kulturową, a późniejsze pochówki zostały wkopane w okolice założenia kamiennego.

Kolejny grób znajdował się w odległości 1,5 m na północ, zawierał trzy naczynia. Jedno z nich, czarne, cienkościenne, posiadało ornament meandra ${ }^{9}$, dwa pozostałe to formy grubościenne, mniej starannie wykonane. Kończąc omawianie urn, autor wspomina o niezdobionej przystawce niewielkich rozmiarów. Opis wyposażenia zamyka wzmianka o umbie (ryc. 6: 22) „Z wysokim dzióbem” (Tymieniecki 1906a, s. 82, tab. III:22). Analogie odnaleźć można wśród egzemplarzy zaliczonych przez T. Lianę do grupy J.7a, odmiany 2 (Liana 1970, tabl. IV:13, s. 452) i w związku z ich przynależnością do 5 grupy grobów z bronią wyróżnioną przez K. Godłowskiego należy je datować na fazę Cla (Godłowski 1992, s. 72).

Kolejne „badania” miały miejsce kilka dni później po drugiej stronie wąwozu. Tam w trakcie dwudniowych poszukiwań badacz zanotował obecność piasku zmieszanego ze spalenizną, co interpretuje jako miejsce palenia stosu pogrzebowego, gdzie znalazł także przepalone naczynia oraz przedmioty metalowe (Tymieniecki 1906a, s. 83). Z opisu wynika, iż „warstwa piasku zmieszanego z popiołem, węglem i szczątkami kości (rozciągała się) na przestrzeni około pięciu łokci” (co daje przestrzeń około $3 \mathrm{~m}$ ), natomiast miąższość wynosiła „przeszło sześć cali” (w przybliżeniu $15 \mathrm{~cm}$ ) (Tymieniecki 1906a, s. 82-83). Sądząc z opisu, możemy mieć tu do czynienia $\mathrm{z}$ cmentarzyskiem warstwowym, a raczej z grobem warstwowym, czyli rodzajem obiektu, który można identyfikować z grobem jednostkowym. Miąższość takich założeń waha się od około $5 \mathrm{~cm}$ do maksymalnie $10 \mathrm{~cm}$ (Błażejewski 2015 , s. 202, 206). A ponieważ groby takie często charakteryzują się skomplikowaną stratygrafią i możliwością zalegania różnych warstw ciałopalenia nad sobą na wielu poziomach, stąd możliwa znaczna miąższość zanotowana przez XIX-wiecznego badacza (Tymieniecki 1906a, s. 83; Błażejewski 2015, s. 206). Ze względu na bardzo skąpy opis, niestety, nie można pokusić się tu o dokładniejszą analizę rozpoznanego pochówku.

W dalszej części artykułu zamieszcza opis przedmiotów odkrytych w trakcie dwudniowych „badań” prowadzonych w Kwiatkowie i okolicy. Przy czym zaznacza, że z konieczności opisywania wszystkich przedmiotów pochodzących z Kwiatkowa zwalniają go już wcześniejsze publikacje, gdzie zabytki te zostały

\footnotetext{
${ }^{9}$ Analogie wśród form typu I/2 wyróżnionych przez T. Lianę występują głównie w fazie B1 okresu rzymskiego (1970, s. 438-439).
} 


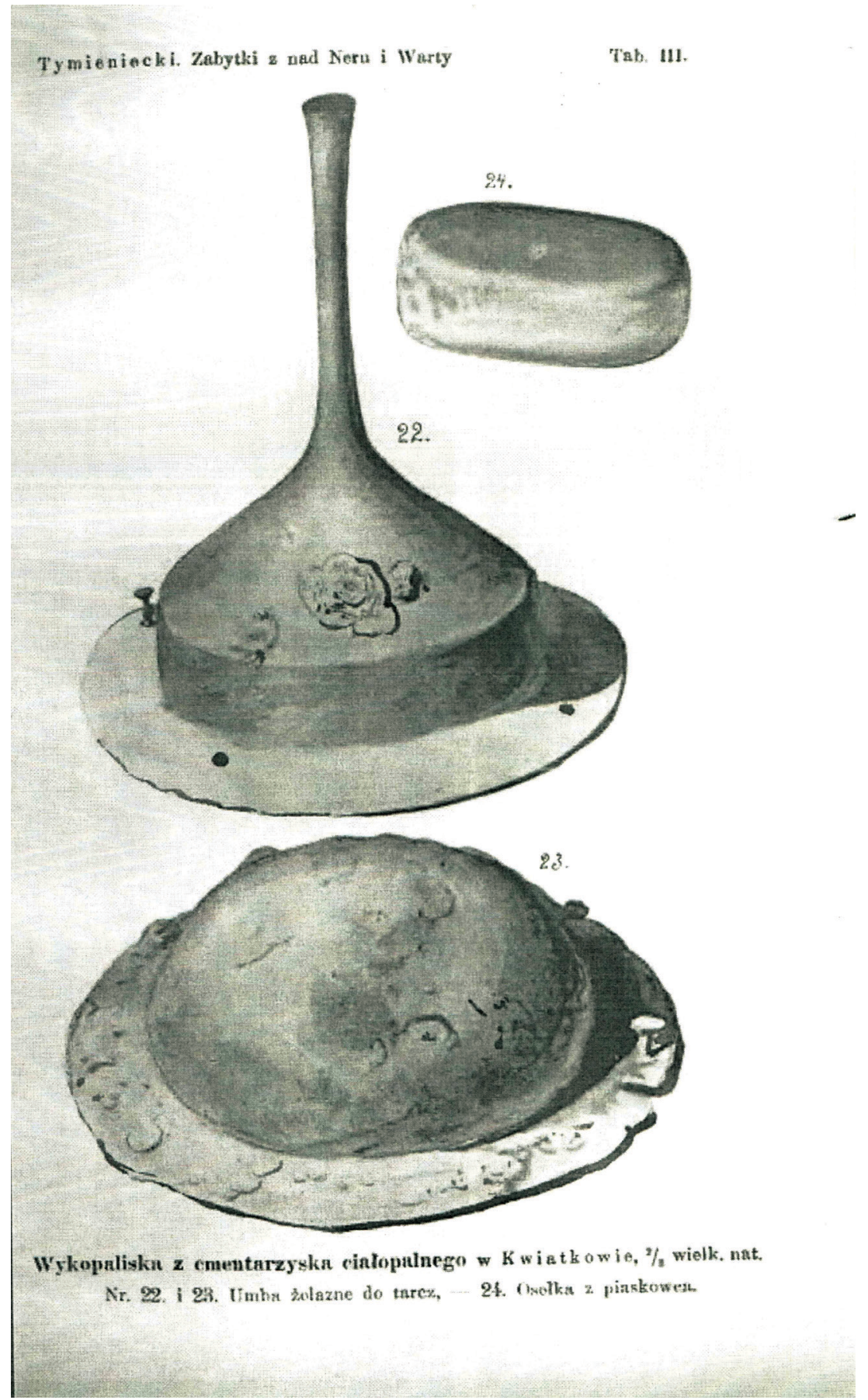

Ryc. 6. Zabytki z cmentarzyska w Kwiatkowie (Tymieniecki 1906a, tabl. III) 
zamieszczone. Tym razem Tymieniecki prezentuje w większości zabytki kultury przeworskiej ${ }^{10}$, takie jak: zapinki, igły, noże, klamry do pasa, grzebienie, imacze, pogięty miecz, umba, elementy skrzyneczek (Tymieniecki 1906a, s. 83, tabl. I-III). Wśród prezentowanych zabytków można odnaleźć dwie fibule typu AII, 41 (odmiana A.41 Y; ryc. 4:1, 2), które występują głównie w fazie B2/C1 (Tymieniecki 1906a, s. 83-84, tabl. I:1-2; Schuster 2006, s. 101, 105). Kolejne fibule to typ A68 (ryc. 4:3) datowana na fazę B1, a dokładnie na podfazę B1b (Tymieniecki 1906a, s. 84, tabl. I:3; Liana 1970, s. 441-442) oraz typ A 236 (ryc. 4:4; Tymieniecki 1906a, s. 84, tabl. I:4; Almgren 1923). Tymieniecki pomija natomiast przedstawioną graficznie fibulę trąbkowatą A.75 (ryc. 4:1), którą można zaliczyć do odmiany 2. wg T. Liany (Tymieniecki 1906a, tabl. I:5; Liana 1970, s. 443). W następnej kolejności wspomina o odkryciu dwóch grzebieni kościanych, które dokładnie charakteryzuje, zamieszczając rysunek jednego z nich (ryc. 4:11). Na tej podstawie można sądzić, iż jest to okaz jednodzielny, wieloczęściowy połączony podłużnymi nitami typu B wg S. Thomas, a datować go można na fazę B2 i początek fazy C1 (Tymieniecki S. 1906a, s. 84, tabl. I:11; Thomas 1960).

Dalej wymienia znaleziska żelaznych przedmiotów wartych według niego uwagi, jednak nie wiadomo dokładnie, skąd owe pochodzą, czy jest to zbiór przedmiotów z przeprowadzonych prac, czy należy łączyć je z grobem warstwowym, czy zbiorem przedmiotów żelaznych umieszczonych w grobie pierwszym (?). Wśród wymienionych zabytków można odnaleźć opisany już wcześniej miecz (powiązany z grobem pierwszym), jedenaście grotów o długości od 14 do $40 \mathrm{~cm}$, pięć $u_{m b}{ }^{11}, \mathrm{z}$ których dwa mają analogię wśród okazów zaprezentowanych w „Pamiętniku Fizyograficznym", a więc są to typy J7a (odmiany $1 \mathrm{wg}$ T. Liany) (por. Tymieniecki 1881, tabl. XIII:7-8; 1906a, s. 85; Liana 1970, s. 451-452; Zieling 1989, s. 1015, 1049). Wymienia ponownie opisane wcześniej umbo typu J7a (odmiany 2 wg T. Liany) (por. Tymieniecki 1906a, s. 82, 83; Liana 1970, tabl. IV:13, s. 452). Ostatni wymieniony okaz to umbo półkuliste (ryc. 6: 23), które należy do 6. grupy grobów z bronią i może być datowane na fazę C1b (Tymieniecki 1906a, s. 85, tabl. III:23; Godłowski 1992, s. 74). Wśród dwunastu odnalezionych noży na uwagę, według S. Tymienieckiego, zasługują trzy. Pierwszy z nich to nożyk sierpikowaty z trzonem do rękojeści (ryc. 4:9; grupa $3 \mathrm{wg} \mathrm{T}$. Liany) łączony z drugą fazą podokresu B2 (Tymieniecki 1906a, s. 85, tabl. I:9; Liana 1970, s. 449). Dwa kolejne to identyczne egzemplarze o długości $10 \mathrm{~cm}$ (ryc. 4:10), których forma wydaje się nawiązywać do wcześniej już omówionego okazu z „Pamiętnika...” (Tymieniecki 1881, tabl. XIII:15; 1906a, s. 85, tabl. I:10). W dalszej części swojej pracy wskazuje na odnalezienie czterech imaczy, dwa z nich odpowiadają zaprezentowanemu we wcześniejszym artykule typowi J.9 (por. Tymieniecki 1881, tabl. XIII:9), dwa kolejne (ryc. 5:20) należą do typu J.6 wiązanego z fazą B1a-b

\footnotetext{
10 Wyjątek stanowi szpila z łabędzią szyją (Tymieniecki S. 1906a, tabl. I:13).

11 Tymieniecki opisuje jedynie cztery $\mathrm{z}$ nich.
} 


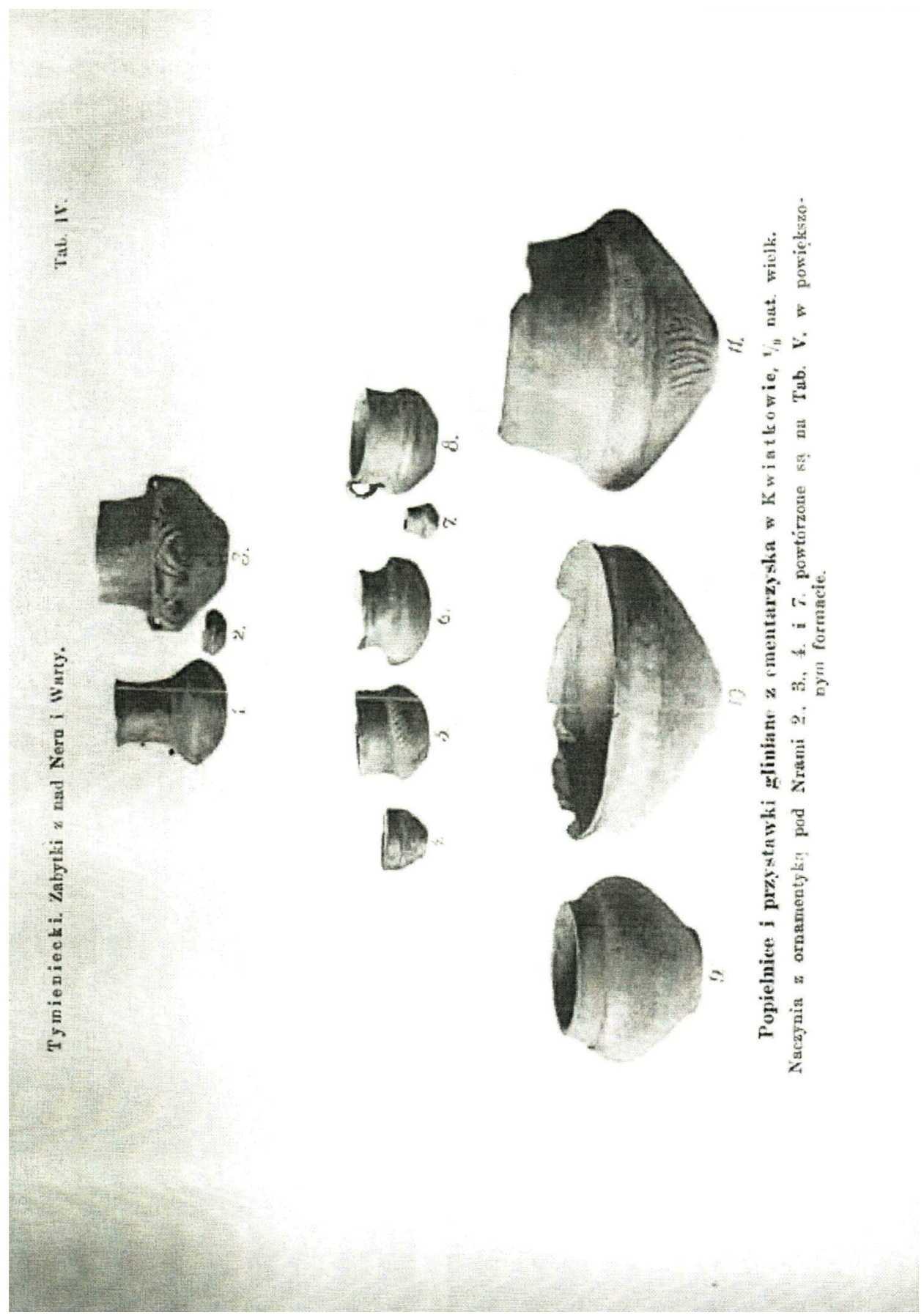

Ryc. 7. Zabytki z cmentarzyska w Kwiatkowie (Tymieniecki 1906a, tabl. VI) 
(Tymieniecki 1906a, s. 85, tabl. II:20; Godłowski 1992, s. 72). Następnie jedynie wymienia znalezione zabytki: trzy pary nożyc i fragment sierpa.

$\mathrm{Na}$ zamieszczonych przez niego rycinach widnieją również elementy skrzynek (ryc. 4:15; 5:17; Tymieniecki 1906a, s. 86, tabl. I:15, II:17). Niezbyt wyraźna rycina może przedstawiać okucie zamka (ryc. 5:17; Tymieniecki 1906a, tabl. II:17). To dwie blaszki połączone w narożnikach czterema nitami, w dolnej znajduje się prostokątny otwór, w górnej, przez całą długość, biegnie czworoboczna rynienka. Przedstawione okucie swoją formą może nawiązywać do typu $12 \mathrm{w}$ typologii A. Kokowskiego, z tą różnicą, że zamiast rynienkowatego kanału do wprowadzania klucza mamy czworoboczny (Kokowski 1997, s. 36). Kolejna część składowa skrzynki została opisana przez autora jako ,żelazko w formie wędzidła”, jest to element okucia skrzyni, najprawdopodobniej jej zawias (ryc. 4:15; Tymieniecki 1906a, s. 86, tabl. I:15; Czarnecka 2007, Taf. CCLXXIII:5). W części dotyczącej elementów skrzynek autor wymienia „dwie skówki ... może dopełnieniem jednego (zamka) będące" (ryc. 5:18; Tymieniecki 1906a, s. 86, tabl. II:18). Autor nie podaje wymiarów owych przedmiotów, jednak przypominają one raczej okucia nakładane na pas. Pojawił się również opis dwóch zapinek A162 (ryc. 4:6), jednak sposób przedstawienia nie pozwala na szczegółowe rozważania typologiczne (Tymieniecki 1906a, tabl. I:6; Almgren 1923; Olędzki, Ziętek 2017, s. 363), oraz bliżej niezidentyfikowanego szydła (Tymieniecki 1906a, s. 86). Autor wymienia również dwie szpile, jedna $\mathrm{z}$ nich to żelazny okaz z łabędzią szyją i spłaszczoną główką zwiniętą w uszko (ryc. 4:13). Zabytek ten należy wiązać z kulturą łużycką z wczesnego i środkowego okresu lateńskiego (Tymieniecki 1906a, s. 86, tabl. I:13; Łuka 1952, s. 141). Druga ze „szpil” jest bardziej osobliwa i nie znajduje odpowiednika wśród zabytków wiązanych z kulturą łużycką czy przeworską (ryc. 4:12; Tymieniecki S. 1906a, tabl. I:12). Cały korpus pokrywa ornament krzyżujących się linii rytych, z jednego jej końca wyrzeźbiono kształt „głowy”, drugi zakończony jest trójkątnie. Nie można wykluczyć, że jest to destrukt bliżej niezidentyfikowanego przedmiotu, szpili z łabędzią szyją lub naszyjnika, który autor badań zinterpretował właśnie w taki, przedstawiony na rycinie, sposób.

Pośród umieszczonych na tablicach artefaktów znalazły się również naczynia odkryte przez badacza. Większość z nich to formy, które należy wiązać z kulturą łużycką (ryc. 7:1-3, 5-11; 8:2-4; Tymieniecki 1906a, tabl. IV:1-3, 5-11, tabl. V:2-4). Wśród nich charakterystyczna jest amfora datowana na IV-V okres epoki brązu (ryc. 7:3; 8:3; Tymieniecki 1906a, tabl. IV:3; V:3; Durczewski 1986, s. 94).

W podsumowaniu artykułu Tymieniecki, analizując odkryte zabytki ceramiczne, słusznie zauważa, iż różnią się one nie tylko pod względem formy, ale i ornamentyki oraz użytego materiału. Odnotowuje również, że w jednym grobie obok naczyń „kunsztownej roboty”, znalazły się naczynia wykonane w zupełnie odmienny sposób, co pozwala mu wysunąć stwierdzenie, że „całe wieki dzielą te wyroby ludzkiej ręki” (Tymieniecki 1906a, s. 87). Tymieniecki jako archeolog amator wykazał się tu zatem dużą intuicją, ponieważ bez wątpienia piaszczyste wyniesienie 


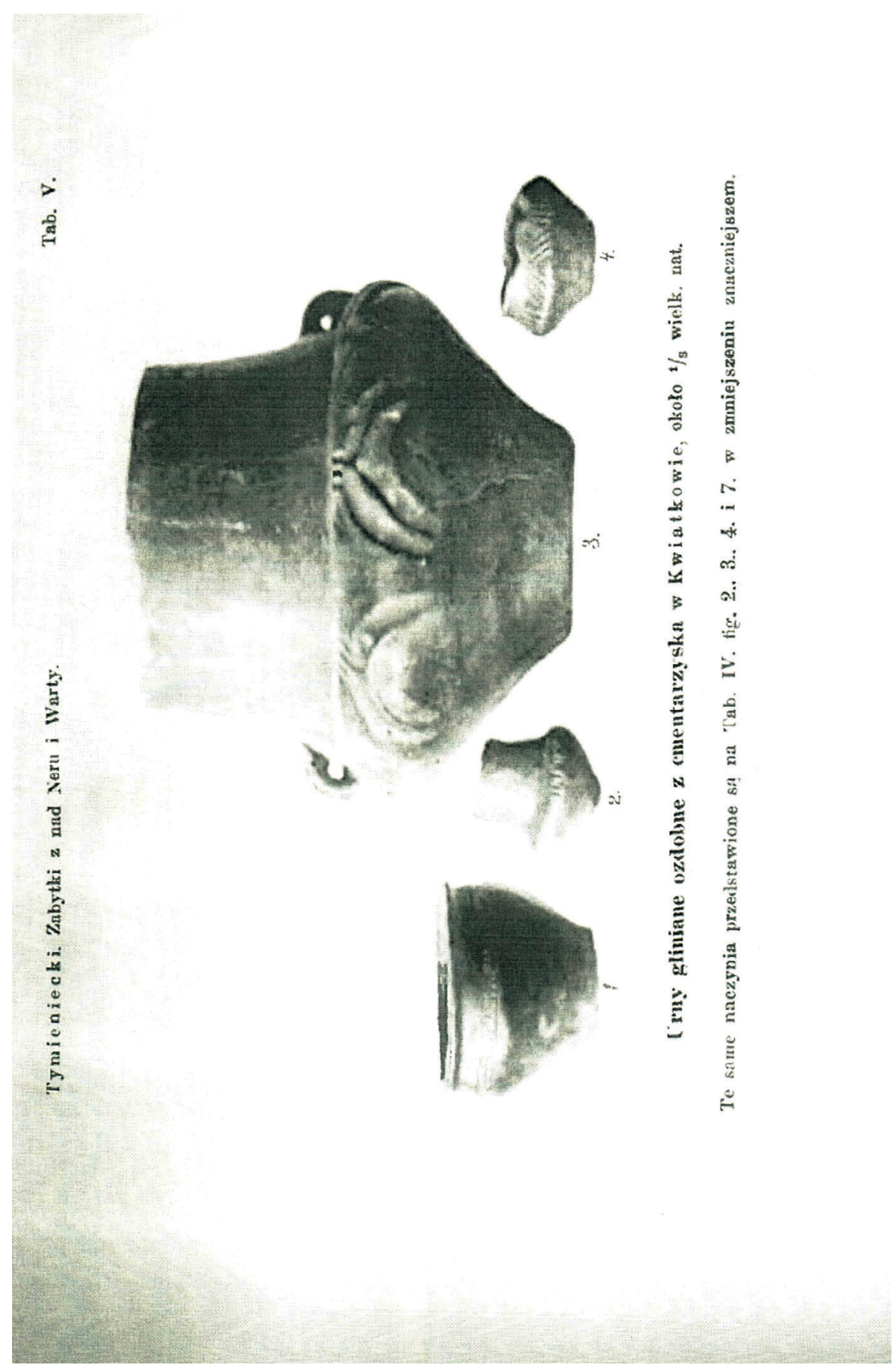

Ryc. 8. Zabytki z cmentarzyska w Kwiatkowie (Tymieniecki 1906a, tabl. V) 
w Kwiatkowie było miejscem grzebania zmarłych przez długi czasu, użytkowanym przez przedstawicieli co najmniej dwóch kultur.

Nie powinno to dziwić, gdyż z okolic Brudzewa znanych jest ponad 80 stanowisk archeologicznych wiązanych z kulturą łużycką i ponad $150 \mathrm{z}$ kulturą przeworską (Rzepecki, Kot i Piotrowska 2016, s. 137-186). W sprawozdaniu załączonym do teczki obszaru AZP o numerze 59-44, w którego ramach zlokalizowane jest stanowisko Kwiatków 11/20, zamieszczono również wzmiankę dotyczącą 5 stanowisk sepulkralnych: 2 stanowisk kultury łużyckiej i 3 kultury przeworskiej. Dla rozważań w niniejszym artykule ważne są jedynie dwa z nich, które można brać pod uwagę jako te, które mógł eksplorować Tymieniecki. Jak pisze autor sprawozdania, kwestia tych nekropoli pozostaje niewyjaśniona, a wątpliwości dotyczą ich lokalizacji. Ze sprawozdań Tymienieckiego wyraźnie wynika, iż badane przez niego groby położone były na piaszczystych wzgórzach (Tymieniecki 1878, s. 76; 1881, s. 1; 1906a, s. 81), co pokrywa się z lokalizacją stanowisk z arkusza AZP, które obecnie są zalesione i niedostępne do archeologicznej weryfikacji, a znajdują się w okolicy miejscowości Gaj (Gorczyca K., Sprawozdanie...), nie zaś samego Kwiatkowa. Paradoksalnie sytuację wyjaśnia sam Tymieniecki w jednym z artykułów „W takiej to okolicy... leży wieś Kwiatków, a w granicach jej miejscowości zwanej Gaj, wśród piaszczystych wzgórków między ramionami Warty i Neru cmentarz przedhistoryczny" (Tymieniecki S. 1906a, s. 81).

Badane przez kaliskiego miłośnika archeologii cmentarzyska nie są, niestety, tymi, które można by łączyć ze stanowiskiem Kwiatków 11/20 i które mogły tworzyć wraz z nim kompleks osadniczy. Biorąc pod uwagę rangę odkrytej osady, która była prężnie rozwijającym się ośrodkiem na trasie „szlaku bursztynowego”, oraz długość jej zasiedlenia, powiązane z nią cmentarzysko powinno wyróżniać się nie tylko rozmiarami, bogatym wyposażeniem, ale i rozbudowaną chronologią. Wielkość cmentarzysk odkrywanych w Wielkopolsce, których czas użytkowania przypadał na podobne ramy czasowe jak funkcjonowanie osady w Kwiatkowie 11/20 (młodszy okres przedrzymski po okres wędrówek ludów), wahała się od 0,5 do 2,25 ha, znamienna była również duża liczba pochówków (od 159 do 772) (Dąbrowscy 1967; Żychliński 2014, s. 68-69). Biorąc pod uwagę XIX-wieczną „metodykę" prowadzenia badań, tak duże i przede wszystkim bogate w artefakty cmentarzysko nie uszłoby uwadze ówczesnych archeologów-pasjonatów.

Ostatnią przesłanką wykluczającą możliwość korelacji cmentarzyska w Gaju i osady w Kwiatkowie 11/20 jest dzieląca je odległość, która wynosi niemal 2,40 km. Na podstawie innych, choć nielicznie odkrywanych, zespołów osadniczych widać, że dystans dzielący osadę i odpowiadające jej cmentarzysko były dużo mniejsze i np. w Wólce Łasieckiej, gm. Bolimów wynosił około 100 m (Bender 1980, s. 335-332; Bender i Dąbrowska 2012, s. 161), a w Wólce Domaniowskiej, stan. 6 i 6a, gm. Przytyk to 150 m (Olędzki M. 1997, s. 51, ryc. 1$)$. 


\section{BIBLIOGRAFIA}

Abramowicz A. 1991, Historia archeologii polskiej. XIX i XX wiek, Warszawa-Łódź.

Almgren O. 1923, Studien über nordeuropäische Fibelformen der ersten nachchristlichen Jahrhunderte mit Berücksichtigung der provinzialrömischen und südrussischen Formen, Leipzig.

Baranowski T. 1995, Archeologia i numizmatyka - pasje naukowe i popularyzatorskie Seweryna Tymienieckiego, „Rocznik Kaliski”, t. XXV, s. 14-23.

Bender W. 1980, Kompleks osadniczy w miejscowości Wólka Lasiecka na tle osadnictwa dorzecza Bzury, „Archeologia Polski”, t. 25 (2), s. 335-392.

Bender W., Dąbrowska T. 2012, Materiaty ze stan. 1 w Wólce Łasieckiej, gm. Bolimów, pow. skierniewicki, „Wiadomości Archeologiczne”, t. 63, s. 161-225.

Biborski M. 1978, Miecze z okresu wplywów rzymskich na obszarze kultury przeworskiej, „Materiały Archeologiczne", t. 18, s. 53-162.

Błażejewski A. 2015, W kwestii definicji grobów warstwowych z okresu rzymskiego, w: L. Tyszler, E. Droberjar (red.), Barbari Superiores et Inferiores. Archeologia Barbarzyńców, Łódź-Wieluń, s. 199-210.

Czarnecka K. 2007, Oblin. Ein Graberfeld der Przeworsk-Kultur in Sudmasowien, „Monumenta Archaeologica Barbarica", t. 13, Warszawa.

Dąbrowska T. 1995, Późne odmiany fibul silnie profilowanych w Polsce, „Wiadomości Archeologiczne”, t. 53 (1), s. 3-34.

Dąbrowscy I., K. 1967, Cmentarzysko z okresów późnolateńskiego i wpływów rzymskich w Wesótkach, pow. Kalisz, „Polskie Badania Archeologiczne”, t. 15, Wrocław.

Domański G. 1979, Kultura luboszycka między Łaba a Odra w II-IV wieku, Wrocław.

Durczewski D. 1986, Cmentarzysko ludności kultury łużyckiej z IV-V okresu epoki brąu w Kaliszanach, woj. pilskie, „Fontes Archaeologici Posnanienses”, t. 35, Poznań, s. 41-98.

Godłowski K. 1992, Zmiany w uzbrojeniu ludności kultury przeworskiej w okresie wpływów rzymskich, w: M. Głosek, A. Nadolski (red.), Arma et Ollae: studia dedykowane Andrzejowi Nadolskiemu w 70 rocznicę urodzin i 45 rocznicę pracy naukowej: sesja naukowa, Łódź, 7-8 maja 1992 r., Łódź, s. 71-88.

Godłowski K. 1970, The Chronology of the Late Roman and Early Migration Periods in Central Europe, „Prace Archeologiczne”, t. 11, Kraków.

Godłowski K. 1985, Przemiany kulturowe i osadnicze w południowej i środkowej Polsce w młodszym okresie przedrzymskim $i$ w okresie rzymskim, „Prace Komisji Archeologicznej, Polska Akademia Nauk. Oddział w Krakowie. Komisja Archeologiczna”, nr 23.

Gorczyca M. Sprawozdanie. Archeologiczne Zdjęcie Polski, obszar 59-44. Sprawozdanie załaczone do teczki 59-44, s. 1-2. Teczka z kartami AZP w Muzeum w Koninie.

Jażdżewska M., Siciński W. 2017, Siemiechów stanowisko 2, województwo łódzkie. Cmentarzysko i osada kultury przeworskiej, Łódź.

Kaszewski Z. 1969, Cmentarzysko kultury tużyckiej z V okresu epoki brązu i wczesnego okresu epoki żelaza na stanowisku 1 w Praszce, pow. Wieluń, „Prace i Materiały Muzeum Archeologicznego i Etnograficznego. Seria archeologiczna", nr 16, Łódź, s. 67-105.

Kot K. 2016, Ceramika z okresu przedrzymskiego, rzymskiego i wędrówek ludów, w: S. Rzepecki (red.), Wielokulturowy kompleks osadniczy ze stanowiska Kwiatków 11/20. Strefy A1 i A2, Spatium Archaeologicum, t. 9, Łódź, s. 141-274.

Kot K., Piotrowska M. 2016, Zabytki pozaceramiczne z okresów przedrzymskiego, rzymskiego i wędrówek ludów ludów, w: S. Rzepecki (red.), Wielokulturowy kompleks osadniczy ze stanowiska Kwiatków 11/20. Strefy A1 i A2, „Spatium Archaeologicum”, t. 9, Łódź, s. 275-286.

Kot K., Piotrowska M., Schellner E. 2015, Osada kultury przeworskiej z okresu przedrzymskiego i okresu rzymskiego $w$ Kwiatkowie, stan. 11 nad środkowa Warta. Stań badań i zakres poznawczy, w: L. Tyszler, E. Droberjar (red.), Barbari Superiores et Inferiores. Archeologia Barbarzyńców, Łódź-Wieluń s. 315-328.

Kokowski A. 1970, Schlossbeschläge und Schlüssel im Barbaricum in der römischen Kaiserzeit Und der frühen Völkerwanderungszeit: Klassifizierung, Verbreitung, Chronologie, „Klasyfikacja zabytków archeologicznych", t. 2. 
Kraszewski J.I. 1860, Sztuka u Słowian, szczególnie w Polsce i Litwie przedchrześcijańskiej, Wilno.

Liana T. 1970, Chronologia względna kultury przeworskiej we wczesnym okresie rzymskim, „Wiadomości Archeologiczne", t. 35, s. 429-492.

Łuka L.J. 1952, Cmentarzysko z wczesnego i środkowego okresu lateńskiego, „Fontes Praehistorici”, t. 3, s. $98-149$.

Madyda-Legutko R. 1986, Die Gürtelschnallen der römischen Kaiserzeit und die frühen Völkerwanderungszeit im mitteleuropäischen Barbaricum, B.A.R. Int. Series 360, Oxford.

Olędzki M. 1997, Fibule z cmentarzyska kultury przeworskiej w Wólce Domaniowskiej koło Radomia, „Acta Universitatis Lodziensis. Folia Archaeologica”, t. 21, s. 51-70

Olędzki M. 1998, Rollenkappenfibeln der östlichen Hauptserie Almgren 37-41 und die Varianten Fig. 42-43, w: J. Kunow (red.), 100 Jahre Fibelformen nach Oscar Almgren internationale Arbeitstagung, 25-28. Mai 1997, Kleinmachnow, Land Brandenburg. Forschungen zur Archäologie im Land Brandenburg, t. 5, s. 67-84.

Olędzki M., Ziętek J. 2017, Typologia, chronologia i rozprzestrzenienie fibul typu A.162 na terytorium kultury przeworskiej, w: E. Droberjar, E. Komoróczy (red.), Řimské a germánské spony ve středni Evropě (Archeologie barbarů 2012), Brno, s. 363-383.

Piotrowska M. 2016, Osadnictwo z okresu przedrzymskiego, okresu wplywów rzymskich $i$ wczesnego okresu wędrówek ludów. Perspektywa źródel nieruchomych, w: S. Rzepecki (red.), Wielokulturowy kompleks osadniczy ze stanowiska Kwiatków 11/20, gm. Brudzew. Strefy A1 i A2, Spatium Archaeologicum, t. 9, Łódź, s. 47-140.

Rzepecki S., Kot K., Piotrowska M. 2016, Pod prąd czasu. Kwiatków i okolica w pradziejach, Łódź.

Schuster J. 2006, O późnych zapinkach kapturkowych (A II 41), „Wiadomości Archeologiczne”, t. 58, s. $101-120$.

Thomas S. 1960, Studien zu den Germanischen Kämmen der römischen Kaiserzeit, „Arbeits- und Forschungsberichte zur Sächsischen Bodendenkmalpflege”, t. 8, Stuttgart, s. 54-215.

Tymieniecki S. 1878, Wiadomość o cmentarzyskach przedhistorycznych, odkrytych w Kaliskiem. Zabytki przedhistoryczne znad Neru i Warty, a zwłaszcza cmentarzysko w Kwiatkowie, „Zbiór Wiadomości do Antropologii Krajowej”, t. 2, s. 75-76.

- 1881, Żalnik w Kwiatkowie, „Pamiętnik Fizyograficzny”, t. 1, s. 393-398.

- 1904, Zabytki przedhistoryczne znad Neru i Warty, a zwłaszcza cmentarzysko w Kwiatkowie, „Gazeta Kaliska”, nr 227 (z 5.8.1904), s. 1-2; nr 228 (z 6.8.1904), s. 1-2.

Tymieniecki S. 1906a, Zabytki przedhistoryczne z nad Neru $i$ Warty, a zwlaszcza cmentarzysko w Kwiatkowie, „Materyały Antropologiczno-Archeologiczne i Etnograficzne”, t. 8, s. 77-87.

- 1906b, Zabytki przedhistoryczne z nad Neru $i$ Warty, a zwlaszcza cmentarzysko w Kwiatkowie, „Rocznik Prawników Kaliskich (za lata 1903-1904)”, Kalisz, s. 86-95.

Słownik 1993, Stownik bibliograficzny Wielkopolski potudniowo-wschodniej (zeszyt próbny), Kalisz, s. 29-30;

Słownik 1983, Słownik bibliograficzny adwokatów polskich S-Ż, t. 1, Warszawa, s. 448-449.

Tyszler L. 2012, Ceramika rzymska na pótnoc od Karpat, „Spatium Archaeologicum”, t. 4, Łódź.

Zieling N. 1989, Studien zu germanischen Schilden der Spätlatène- und der römischen Kaiserzeit im freien Germanien, B.A.R. Int. Series 505 (1-3), Oxford.

Żychliński D. 2014, Obrządek pogrzebowy ludności kultury przeworskiej i wielbarskiej w Wielkopolsce, „Prace Archeologiczne”, t. 1. 